Walisongo Law Review (Walrev), Vol 1 No. 2 (2019)

DOI: 10.21580/Walrev/2019.1.2.4816

Copyright @ 2019 Walisongo Law Review (Walrev)

Walisongo Law Review

\title{
Implementation of Technology Transfer Based on Law No. 25 of 2007 on Investment in the Context of Development of Industry in Indonesia
}

\author{
A. Hashbi Luthfi \\ Afiliasi: Universitas Islam Negeri (UIN) Sunan Kalijaga, Yogyakarta \\ e-mail: a.luthfi@uin-suka.co.id
}

\begin{abstract}
Legal arrangements in the field of technology transfer related to foreign investment need to be considered in order for the entry of new technology in Indonesia. This article aims to know how the implementation of Technology Transfer under Law No. 25 of 2007 on Investment in Indonesia and Transfer of technology developments in Indonesia with the Law No. 25 Year 2007 on Investment. The method used is a normative juridical analytical descriptive, whereas in analyzing the data using qualitative methods and presented descriptively. From this study shows that the main problem at the root problem of transfer of technology in Indonesia is the law governing the transfer of technology itself. That's because there is no obvious technical regulations regarding foreign investment for technology transfer in the discourse of transfer of technology as stipulated in Law No. 25 of 2007 on Investment is only optional and not become an obligation for foreign investors to come. It was concluded that the concept of technology transfer in foreign investment in Indonesia is based on the principle of self-reliance, development Technology transfer through foreign
\end{abstract}


investment in Indonesia has not had a clear regulation so here said technology transfer is only seen as a choice for investors not as a an obligation which is binding and accompanied with strict punishment.

Pengaturan hukum di bidang alih teknologi yang terkait dengan investasi asing perlu dipertimbangkan untuk masuknya teknologi baru di Indonesia. Artikel ini bertujuan untuk mengetahui bagaimana implementasi transfer teknologi berdasarkan UU No. 25 tahun 2007 tentang Investasi di Indonesia dan transfer perkembangan teknologi di Indonesia dengan UU No. 25 Tahun 2007 tentang Investasi. Metode yang digunakan adalah deskriptif analitik yuridis normatif, sedangkan dalam menganalisis data menggunakan metode kualitatif dan disajikan secara deskriptif. Dari penelitian ini menunjukkan bahwa masalah utama pada akar masalah transfer teknologi di Indonesia adalah hukum yang mengatur transfer teknologi itu sendiri. Itu karena tidak ada peraturan teknis yang jelas mengenai investasi asing untuk transfer teknologi dalam wacana transfer teknologi sebagaimana diatur dalam Undang-Undang Nomor 25 Tahun 2007 tentang Investasi hanya opsional dan tidak menjadi kewajiban bagi investor asing untuk datang. Dapat disimpulkan bahwa konsep alih teknologi dalam investasi asing di Indonesia didasarkan pada prinsip kemandirian, pengembangan Transfer teknologi melahi investasi asing di Indonesia belum memiliki regulasi yang jelas sehingga disini dikatakan transfer teknologi hanya dipandang sebagai pilihan bagi investor bukan sebagai kewajiban yang mengikat dan disertai dengan sanksi tegas.

Keywords : Technology Transfer; Development; Industry.

\section{Introduction}

Industry is part of the economic production which focus on specific manufacture development process, usually have to have a large capital before they can grow and earn profits. In the industry, we can find an element of integration between technology and economy. Strong industry and can compete with competitors is an industry that is based on strong technological capabilities and economic system that is reliable, while the 
industry that is not supported by the ability of adequate technology will soon become the industry are obsolete and outdated, as well as the industry that does not have strong economic foundation will be fragile industry that need protection and subsidies on an ongoing basis.

In the 1990, is often cited as the beginning of the era of globalization. Some experts interpret the globalization era is an era where thanks to advances in information technology, communications and transportation increasingly rapid and sophisticated, the orientation of thoughts, interests, and all efforts of man to realize the importance and achieve an increasingly regional scope includes global as well.

In the economic field such as occurs increasingly fierce competition, while there is also the development of the value and size of the aspects of human life, in social, economic, political and security. Of course, the impact of globalization is a very serious challenge for developing countries, because the economic strength and mastery of technology is still limited when compared with the economic and technological capabilities developed countries. In such conditions, the quality of human resource factors in relation to mastery of technology, foresight and cleverness take advantage of opportunities and overcome obstacles is an important factor for the nations in guaranteeing their own national interests.

The issue of economic globalization is increasingly prevalent after approval and signing of the GATT-Uruguay Round agreement by the 122 member states in Marrakesh, Morocco on April 15, 1994 (Marrakesh Meeting). At the meeting also approved the name change of the GATT (General Agreement On Tariffs And Trade) to the WTO (World Trade Organization) or the World Trade Organization. GATT (general agreement on tariffs and trade) is a multilateral trade agreement in force since 1948 with the main objectives are (Syahmin, 2007: 35):

a. Trade liberalization to increase the amount of world trade so that production increases.

b. Fighting the reduction and removal of barriers - barriers to trade in the form of tariff barriers (tariff barriers) as well as other barriers (non-tariff barriers). 
c. Regulate trade in services that include the intellectual property rights (intellectual property rights) and investment.

In Indonesia the industry as an integral part of the national economic order to be able to take advantage of any opportunities to develop industrial technology in conducting business activities and address the threats arising from the globalization era. This is very important because now the industrial sector has become one of the pillars of national economic development of Indonesia.

For developing countries like Indonesia to develop its construction in order to succeed does not have to find or create the technology itself, but it would be more efficient if it takes over the technology from other countries that have developed the technology through direct investment or by way of a license agreement. As disclosed Abdulkadir Muhammad (2001: 11) that in order to improve the ability in the field of Science and Technology one of which can be reached by way of transfer of technology in the framework of investment.

Foreign investment law and the constitution requires a conducive legal, legal certainty in this case is an element as important as the political stability and economic opportunity. Meanwhile, investment growth capital investment, as mandated in Law No. 25 of 2007 on Investment aims to accelerate the development of the national economy. National economic development is intended to embody the political and economic sovereignty of Indonesia, where to realize it necessary to increase investment or investment the economic potential into real economic strength by using capital from internal and foreign parties.

Legal arrangements in the field of technology transfer related to foreign investment also need to be considered in order for the entry of new technology in Indonesia, whether through the cooperation of the license or through foreign investment directly, and if the copyright holder has the right to license to other parties under licensing agreements the. For that, it needs to spell out unequivocally to be the mechanism of technology transfer from foreign technology owners to Indonesian technology, resulting in the production of a technology will be extended to countries in the developing world. 
Law as a means of social reform should be able to provide the adjustment to the new developments, for the transfer of technology also needs to be regulated by the laws of Indonesia to clear legal certainty for the parties concerned. As a developing country, who realize that science and technology have an important role in accelerating national socio-economic development and particularly in facilitating increased production of goods and services in the industrial sector as well as the inclusion of appropriate foreign technology from abroad into the country with the terms, conditions before the terms and favorable price in the national interest, means it will increase the role of science and technology in the industrial life of the nation of Indonesia.

Based on the categories above shows that the use of new technologies or the transfer of technology, especially in the fields of industry must have adequate arrangements so that the business world will avoid impersonation other technologies, and this is in line with a general agreement on tariffs and trade is a trade agreement multilateral basically aimed at creating free trade, equal treatment and help create economic growth and national development in order to realize human welfare. This is in accordance with the charter Cerds which states that every country has the right to benefit from progress and development of science and technology of other countries to improve the economic and social development (Adolf, 2005: 217).

\section{Implementation of the Legal Framework for Technology Transfer}

The national economy were held based on economic democracy with the principles of togetherness, efficiency with justice, sustainability, environmental friendliness, independence, and keep the balance, advancement and national economic unity ", it is stipulated in Article 33, paragraph 4 of the Constitution of 1945 . The principle is then also implemented in the principles of Investment in Indonesia in Law No. 25 of 2007.

In relation to the principle of independence, the existence of foreign investment by transnational corporations is needed though in practice there 
are some of the companies which then does not disclose information contained in it technology used in the implementation of its production. As a result of technology transfer can not be run in accordance with what is expected by the developing countries (Tampubolon, 2013: 266).

To uphold the principle of independence, then we can learn from the experience of Japan, China, and South Korea are implementing a catch up strategy and applied research. In essence, the technology is divided into two (2) sections, the first section of patented technology; and a second portion that is not patentable including skills (skills) and skills (technical knowhow).

\section{Patent Protected Technology}

Intellectual property protection is the protection of any rights arising from the creativity (creativity) and invention (innovation) pnegetahuan man in science and technology, and in the field of trade and industry.

Within the framework of international law there are agencies WIPO (World Intellectual Property Organization) which is an international organization specifically established to coordinate cooperation among countries in the field of the protection of Intellectual Property Rights (IPR). Indonesia has ratified the Wipo Convention by Presidential Decree No. 24 of 1974 (Wyasa, 2000: 47).

Within the framework of national law Indonesia has legal instruments governing the patent protection, namely in Law No. 14 of 2000. The patent itself is an exclusive right granted by the state to an inventor over his invention results in the field of technology for a given period to own your invention or give consent to others to implement (Sari, 2008: 120).

According to Article 3 of Law 14 of 2000, an invention is new if the invention filed the patent is not the same as previously disclosed technology. To determine whether an invention is new, it must be held prior examination of the data to search for documents published before the date comparison penenrimaan patent application. If the claimed invention patent is not in the comparison document, it is considered to be a new 
invention. The advantage of the presence of this patent among others, include (Lindsay, 2011: 184):

a. Patents help promote technological and economic development of a country;

b. Patents help create an atmosphere conducive to the growth of local industries;

c. Patents help technological and economic development of other countries with licensed facility;

d. Patent assist in the creation of technology transfer from developed to developing countries.

In the practice of the patent application in Indonesia quantitatively explained that the patent application only a few are coming from within the country, in others the largest number coming from abroad. Because of this it is to support and accelerate the pace of indutrialisasi, licensing agreements have a very important role.

The license agreement is a logical consequence of the enactment of the Patent Act, more than that it is part of the globalization of the world economy. Regulation on licensing these patents is important to note that foreign investors feel safe with certainty in legal protection in Indonesia. In article 71 paragraph (1) there is a ban related to the license agreement:

a. License agreement that entail no adverse consequences Indonesian economy;

b. The license agreement contains provisions which prohibited restrictions which hamper the ability of the Indonesian nation in mastering and developing technology in general and with regard to who was granted a patent in particular.

However, problems arising from the article is there is no clear explanation, especially the ban on what is meant and what it meant (Saidin, 2004: 283).

\section{Expertise and Skills}

Expertise (skills) and skills (technical know-how) which, according to Istvan Gazda defined as "knowledge and experience of a technical, 
commercial, administration, financial or other nature, the which is practically applicable to the operation of an enterprise or the practice of a profession." (Gazda, 1996: 1) (technical knowledge and experience, trade, administration, finance or other general matters, practically applicable to the operation of a company or professional practice).

Just a technology may be registered as a patent, but the technology transfer can occur, if the human resources in a country willing to learn and master, even able to develop more advanced technology by relying on technology or the prior art. In practice, only with a willingness to learn constantly and always had confidence through yan experience gained from the process of interaction with the outside world, allowing the principle of independence in the process of technology transfer can be realized in reality.

National regulatory others about the importance of technology transfer for the people of Indonesia can be seen in the Act Sisnas P3 science and technology which states that: "for Indonesia, the transfer of technology through investment enterprises from developed countries has the potential to generate a huge economic impact if the business activities of foreign companies can be associated with a network of domestic manufacturers in the production of value-added chain. Through the association formed the demand-supply mechanism which accompanied with various requirements for quality, performance, and cost of the technology so that domestic manufacturers involved are encouraged to comply.

The transfer of technology through these channels can not be run effectively if domestic enterprises are not ready and not able to meet the requirements of quality, performance, and the cost of technology with international standards so it does not have the eligibility to serve as a supplier of the foreign companies. By contrast the above requirements are met, the domestic enterprises can not only be a supplier for foreign companies who strive in the country, but can also be a supplier of global markets. The best way is to encourage the development of the ability of domestic enterprises in order to have the absorption capacity of the advancement of science and technology. To that end, the partnership business entity with universities and R \& D institutions is a very important factor. Universities and R \& D institutions can act as network nodes that can 
be beneficial for domestic enterprises to monitor and control the progress of science and technology,

Government Regulation No. 20 of 2005 on Intellectual Property and Technology Transfer Research and Development of the Higher Education and Research and Development Institute delegated in Law Number 18 Year 2002 on Sisnas P3 Science, does not give much affirmation of the need for the technology transfer. But only restrict the transfer of technology in the form of interest intellectual property as well as the results of research and development activities, namely (Tampubolon, 2013: 247):

a. To disseminate science and technology;

b. Community capacity to utilize and master of science and technology to the benefit of society and the state.

Within the framework of international law are conventions related to technology transfer concerning patents. Among them are (Saidin, 204: 309):

a. The Paris Convention (Paris Convention for the Protectionof Industrial Property) of this Convention governing industrial property rights. Which became the object of protection of property rights industrial according to this convention are: Patent, utility models (model design), industrial design (industrial design), trade mark (trademark), trade names (names commerce / trade), indication of source or appellation of origin (indication and the original designation). The main principle adopted in the convention is the national treatment principle set out in Article 2 and 3 . According to this principle, "a Uni member states are obliged to treat foreign citizens of other countries members of Uni, the same as its own nationals in matters of patent".

b. Patent Cooperation Treaty (PCT) held an international application system and international publications, examination of international starters on each patent application is more efficient, economical, and simple, if it is desired protection internationally. As for the international petition system under the PCT is as follows: with the possibility to ask for the right of priority based on the Paris 
Convention, every citizen of the countries that entered into an agreement entitled to apply for the PCT.

From the analysis of the legal framework for both national and international legal frameworks above, a major problem is related to the quality of the National Human Resources itself. In addition, it also needs to be considered is related to the coordination between agencies. Foreign investment as a means of technology transfer can not stand alone because foreign investment is also propped on international regulations that are complex and restrictive. Therefore there is need for coordination between institutions, one of them with research and development institutions in accordance with the mandate of Law No. 18 of 2002 to improve the competitiveness and independence of national technology.

\section{Constraints Implementation of Technology Transfer}

Technology can not be separated from efforts to improve the quality standards of commodities produced by a single country. The superiority of a commodity is the inherent superiority of a commodity produced by the country compared to similar commodities produced by other countries.

Opportunities Indonesia as a foreign investment destination has several advantages, namely the absolute advantage (absolute advantage) and comparative advantages (comparative advantage). Absolute advantage (absolute advantage) owned by Indonesia is related to the potency of Natural Resources (SDA) owned. While the comparative advantage (comparative advantage) (Widjaja, 2001: 2) owned by Indonesia is related to the availability factor of production that is associated with labor and cheaper raw materials.

Excellence - excellence of the Indonesian owned provide the main attraction for foreign investment. Foreign investment into Indonesia is then brought technology from developed countries which can be used to enhance the technological capabilities towards national technological independence. Transfer of technology in the investment is not a process without a hitch.

The obstacles found in the current field include (Rakhmawati, 204: 86):

a. External barriers include: 
1. The international system is less supportive, more profitable industrial countries;

2. The bargaining position of developing countries is weak.

b. Internal barriers include:

1. Human resources in large quantities at low levels of education;

2. The lack of the amount of capital available;

3. The technology level is still low;

4. Lack of skills (skills) and knowledge;

5. Weak management and marketing organization;

6. Social and cultural rights are less supportive;

7. Unplanned good education system.

From the constraints described above, there is one obstacle that became an Indonesian technology transfer root causes, namely that the law governing the transfer of technology. Discussion regarding this technology transfer actually has long been a discourse when for the first time Law No. 1 of 1967 concerning Foreign Investment promulgated. Investment Coordinating Board held a variety of activities including academic draft ready on technology transfer.

The enactment of Law No. 25 of 2007 on Investment which berasaskan independence becomes a commitment to place foreign investment into a start to realize the independence and reduce reliance on technology originating from abroad.

This is important, because the reflection of the experience of developed countries, the effort mastery and excellence in the field of science and technology is the key pnegetahuan independence of every nation in the increase in welfare and to win the competition at the global level.

According to Philip L. Gardner, there are at least two issues that have historically impede the transfer of technology to developing countries, namely:

a. technical capacity of developing countries is not sufficient to absorb and use the transferred technology; 
b. in the trade context of international trade, mastery of advanced technology is the comparative advantage of developed countries, where it makes them naturally try to maintain that advantage by creating a mechanism for technology transfer are loaded with requirements or restrictions to prevent the recipient country can master the technology it fully.

\section{The development of Technology Transfer in Indonesia}

In today's modern human life, human beings can not escape from technology. Man who mastered the technology to be honored more in association with the community. Similarly, in the context of the country. Countries that master advanced technology has perceived a higher prestige in the international arena. Not surprisingly, then countries as competing to be at the forefront of technological mastery. For third world countries, this is tantamount to switch the form of being an industrialized country.

One of the main things to enhance technological development is through technology transfer (transfer of technology) in the form of commercial transfer and acquisition of certain technology. Transfer commercial and technology acquisition is the activity of selling and buying an exclusive right to an invention patent or a license to use the know-how where commercial activities were carried out through specific ways that give rise to the legal relationship between the owner (transferor) the person or legal entity obtain the right or license (transferee). Such legal relationship is in the law of contract is a natural thing, so that each party would be acting in good faith in carrying out obligations and rights under the collective agreement (Margono, 2002: 117).

The development of technology transfer in the presence of Act No. 25 of 2007 is the human resources of a company can take a lesson from a training in research and development institution or technical institutes (centers of high learning) by the company conducting the transfer of technology in running the business economy as stipulated in Article 10 of Law No. 25 of 2007 on Investment.

According to Denis Goulet in his book The Uncertain Promise: 
Value Conflicts in Technology Transfers technology not only in the form of equipment or production techniques. Technology is also embodied in a process and person. Technology is defined as the systematic application on human collective rationality to solve the problems by way of seeking control of the natural and human processes. The development of technology transfer in Indonesia itself has an important role because the technology is the source and creator of new resources, technology is a powerful instrument for creating social control, technology influencing decision-maRaja in order to achieve a quality life, and technology form new meanings as opposed to alienation which is the antithesis of a meaningful life (meaningful life).

Analysis of the authors indicate the absence of a clear technical regulations regarding this technology transfer in foreign investment the discourse of transfer of technology as stipulated in Law No. 25 of 2007 on Investment is only optional and not become an obligation for foreign investors to come. This obviously makes it easier for the optional provision criss by foreign investors, which means the development of technology through the transfer of foreign technology is slow and does not meet expectations establishment of Law No. 25 of 2007.

\section{Conclusion}

Based on the description above, it can put forward some conclusions as follows:

The concept of technology transfer in foreign investment in Indonesia is based on the principle of self-reliance. Based on the shape the technology itself is divided into two namely technology protected by patents and patentprotected technologies that are not. In Act No. 25 of 2007 transfer of technologies that are not patent protected done through the training process carried out by the investment company to the national workforce. The Technology Transfer Act No. 25 of 2007 Article 10 carried out by means of training and upgrading the national workforce.

Transfer of technology development through foreign investment in Indonesia has not had a clear regulation so here said technology transfer is only seen as a choice for investors not as a an obligation which is binding and be accompanied with strict punishment. This technology transfer 
should be implemented properly if there is a clear regulation set and requires the transfer of technology as a condition for foreign investors to get a variety of incentives and ease of investing in Indonesia. In addition to the clear regulations, the purpose of foreign investment in Indonesia in accordance with the principle of independence can be achieved, namely enhancing the competitiveness and independence of national technology. $[\mathrm{w}]$

\section{Noted}

Relating to the protection of Intellectual Property Rights (IPR) there are permasalahn complicated. Forum GATT (General Agreement on Tariffs and Trade) which was originally created for the purpose of handling the problem of tariff and trade, since 1980 has expanded its attention toward intellectual property. Conferences GATT, since it is not just limited to discuss the protection of trade marks but even placement issue of intellectual property rights as a whole. See Ida Bagus Putra Wyasa, Aspects of International Law: In International Business Transactions.

Invention (discovery) is the inventor poure idea in any activity of solving a specific problem in the field of technology, can be a product or a process or improvement and development of products and processes.

\section{Reference}

Adolf, Huala. 2005. An Introduction to International Economic Law. Jakarta: PT. Raja Grafindo Persada.

$\mathrm{Ak}$, Syahmin. 2007. International Trade Law in the Framework of Analytical Studies. Jakarta: PT. Raja Grafindo Persada.

Lindsay, Tim. 2011. An Introduction to Intellectual Property Rights. Bandung: Alumni. 
Margono, Suhud and Amir. 2002. Space, Commercialization of Intellectual Assets Business Legal Aspects. Jakarta: PT. Gramedia Widiasarana Indonesia.

Muhammad, Abdulkadir. 2001. Study of Economic Law of Intellectual Property Rights. Bandung: Citra Aditya Bakti.

Rakhmawati, Rosyidah. 2004. Investment Law in Indonesia. Malang: Bayumedia.

Saidin, OK. 2004. Aspects of Intellectual Property Law: Intellectual Property Rights. Jakarta: Raja Grafindo Persada.

Sari, Kartika and Elsi, Advendi Simanunsang. 2008. Law in Economy. Jakarta: Grasindo.

Son, Ida Bagus Wyasa. 2000. Aspects of International Law: In International Business Transactions. Bandung: Refika Aditama.

Tampubolon, Sabartua. 2013. Political Science Law in Indonesia. Yogyakarta: Kepel Press.

Undang-Undang Nomor 25 Tahun 2007 tentang Investasi

Widjaja, Gunawan and Yani, Ahmad. 2001. Series Business Law International Business Transactions: Import-Export and ReturnBuy. Jakarta: Raja Grafindo Persada. 